\title{
Olivine in Carbonatitic and Silicate Rocks in Carbonatite Complexes
}

Gaspar, J.C. ${ }^{1}$; Araújo, D.P. ${ }^{1}$ and Melo, M.V.L.C. ${ }^{1}$

1 - Instituto de Geociências - Universidade de Brasilia - Brasilia, Brazil - 70910-900. debora@guarany.cpd.un.br

Olivine is a common mineral in carbonatite complexes. It usually occurs in dunite, olivine clinopyroxenite, lamprophyre, carbonatite and phoscorite. Few papers on carbonatite complexes contain olivine chemistry data. A set of olivine analysis and/or olivine chemical description occurring in these rocks was found for the Sokli Massif, Finland (Vartiainen, 1980), Jacupiranga Complex, Brazil (Gaspar, 1989 and this work) and Phalaborwa, South Africa (Ericksson, 1989). A large set exists for olivines from the Catalão-I and -II Carbonatite Complexes (Araújo and Gaspar, 1994; Araújo, 1996 and this work).

The Catalão-I and -II Carbonatite Complexes are located the Goiás State, central Brazil. They belong to the Cretaceous Alto Paranaíba Magmatic Province which comprises several alkaline rocks (Bizzi, 1993; Sgarbi and Valença, 1991) and other carbonatites along a NW regional trend (AZ 125). The complexes are intruded in metasedimentary rocks (Araxá Group) of the Neoproterozoic Brasilia Fold Belt which occurs in the southwestern border of the São Francisco Craton. The Catalão-I and-II intrusions are interpreted as cogenetic bodies comprising an ultramafic phase represented by dunite and clinopiroxenite and several carbonatitic phases. The carbonatites had interacted with the primary ultramafic rocks forming carbonate-, phlogopite- and clinopyroxenebearing rocks. Phoscorites also occur and are associated to the carbonatite. In the Catalão-I Complex a breccia with a phlogopite- and olivine- rich matrix cut the former rocks and contains fragments of the intrusion.

Olivine was recovered from dunite $\left(\mathrm{Fo}_{81.7}\right.$ to $\left.\mathrm{FO}_{92.1}\right)$ and phoscorite $\left(\mathrm{Fo}_{84.8}\right.$ to $\left.\mathrm{Fo}_{94}\right)$ fragments in the Catalão-I breccia and from phoscorite $\left(\mathrm{FO}_{78}\right.$ to $\left.\mathrm{FO}_{85.7}\right)$ and lamprophyres (Fo85.7 to Fo87.6) from Catalão-II. Two chemical groups could be distinguished (Figure 1): (1) high Ni- and low Mn- olivines occurring in the Catalão-I dunite $(0.12$ to $0.46 \%$ of $\mathrm{NiO}$ and 0.007 to $0.30 \%$ of $\mathrm{MnO})$ and in the Catalão-II lamprophyre (0,27 to 0,38 of $\mathrm{NiO}$ and 0.12 to $\% 0.22$ of $\mathrm{MnO})$ and (2) low Ni- and high $\mathrm{Mn}$ - olivines found in the Catalão-I and -II phoscorites $(0,0$ to $0,15 \%$ of $\mathrm{NiO}$ and 0,34 to $0,63 \%$ of $\mathrm{MnO}$ for Catalão-I and 0,0 to $0,038 \%$ of $\mathrm{NiO}$ and 0,38 to $0,525 \%$ of $\mathrm{MnO}$ for Catalão-II).

The Jacupiranga Complex is located in the São Paulo state, southeast Brazil, in the border of the Paraná Basin. The Complex is $130 \mathrm{Ma}$ old (Amaral, 1978) and comprises two main intrusions of dunite and magnetite clinopyroxenite. The later is intruded by an ijolite body and an elongated carbonatite intrusion where five carbonatite bodies $\left(C_{1}\right.$ to $\left.C_{5}\right)$ were recognized (Gaspar, 1989). Olivine (Fo92.2 to Fo97.7) occurs in the $\mathrm{C}_{1}, \mathrm{C}_{3}$ and $\mathrm{C}_{4}$ carbonatites. New chemistry data of olivine from carbonatites and dunite were obtained. Dunite olivine (Fo87.9 to $\mathrm{Fo}_{88.8}$ ) presents $\mathrm{MnO}$ between 0.16 to $0.22 \%$ and $\mathrm{NiO}$ between 0.2 to $0.33 \%$. Carbonatite olivine is Mg-rich (Fo92.2 to Fo97.3), presents $\mathrm{MnO}$ higher content $(0.23$ to $0.49 \%)$ and lower $\mathrm{NiO}(<0.04 \%)$. Olivine also occurs in clinopyroxene-bearing dunite, nepheline-bearing phlogopite pyroxenite and olivine monzonite (Gaspar, 1989). Following the above order the forsterite content decrease from 88 to 45 together with $\mathrm{MnO}$ increase (up to $0.69 \%$ ), what was interpreted as a magmatic fractionation trend (Gaspar, 1989).

The Sokli Massif belongs to the Kola Alkaline Province in Finland. It was intruded between 334 and $378 \mathrm{Ma}$ (Kononova et al, 1973 and Vartiainen and Woolley, 1974 in Vartiainen, 1980). The Sokli Massif is composed of carbonatites and ultramafites. The last were interpreted as derived from ultrabasic magmas that intruded before the carbonatites. Intermediate rocks occur as reaction products between carbonatites and former silicate rocks. The ultramafites comprise magnetite olivinite, olivine rock, obicular olivine rock and pyroxenite. Carbonatite rocks include phoscorite and carbonatite. An olivinite forming the Tulppio massif occurs close to Sokli. Olivines compositions are: Tulppio olivinite $\left(\mathrm{Fo}_{91.5}\right.$ ); ultramafites $\left(\mathrm{FO}_{81.7-90.4}\right.$ ); phoscorite (Fo94.6), carbonatite (Fo87-95.5) and 
alkaline lamprophyres (Fo89.1-91.2) (Vartiainen, 1980). The author described two olivine groups: (1) High $\mathrm{NiO}(0.25$ to $0.46 \%)$ and low $\mathrm{MnO}(0.0$ to $0.14 \%)$ for olivine occurring in the Tulppio olivinite and alkaline lamprophyres and (2) low $\mathrm{NiO}(<0.05 \%)$ and high $\mathrm{MnO}(0.59$ to $1.25 \%)$ for olivine in ultramafites, phoscorites and carbonatites.

The Phalaborwa Complex is a Palaeoproterozoic carbonatite mainly composed of clinopyroxenite ( $70 \%$ of the main complex), copper-bearing carbonatite, and phoscorite (Ericksson, 1989). Two periods of carbonatite intrusion occur in the Complex, one as a magnetite-rich rock called banded carbonatite and the transgressive carbonatite containing magnetite and silicate phases. Olivine $\left(\mathrm{FO}_{79}\right.$ to $\left.\mathrm{FO}_{91}\right)$ occurs in the phoscorite and in the banded carbonatite. Ericksson (1989) presents one olivine analysis for each rock. The olivines show low $\mathrm{NiO}$ content $(<0.06 \%)$ and carbonatite olivine has the highest Fo content. There are no data for $\mathrm{Mn}$.

Taking into account the examples given above olivine from carbonatite-related rocks are richer in $\mathrm{Mg}$ content than olivines from silicate rocks for the same complex. Exceptionally high forsterite contents were found for olivine in carbonatites from the Jacupiranga Complex, with a range from 94.9 to $97.7 \mathrm{~mole} \%$ (Gaspar, 1989; this work). Magmatic olivines with Fo contents higher than $95 \mathrm{~mole} \%$ are rare (Deer et al, 1982).

Two olivine chemical groups could be distinguished: (1) high $\mathrm{Ni}$ and low Mn olivine and (2) low $\mathrm{Ni}$ and high $\mathrm{Mn}$ olivines. The first group corresponds to dunite, olivinite and lamprophyre olivines, and the second group corresponds to carbonatite and phoscorite olivines (Figure 1). The exception is the for the ultramafite occurring in Sokli which olivine is Ni-poor and Mn-rich. The chemical similarity between olivines from carbonatite and phoscorite reinforces their genetic relationship as previously proposed by several authors (e.g. Vartiainen, 1980; Lapin, 1982; Yegorov, 1983; Ericksson, 1989; Zaitsev and Bell, 1995, Araújo, 1996).

The main feature to distinguish silicate and carbonatitic-related olivine, together with petrographic and field evidences, is their $\mathrm{Ni}$ and $\mathrm{Mn}$ content. Ericksson (1989) has attributed the low $\mathrm{Ni}$ content of carbonatite olivine to prior magnetite fractionation that would have lowered the $\mathrm{Ni}$ content in the magma. Partitioning data for $\mathrm{Ni}$ between olivine and ultramafic silicate liquid suggests that $\mathrm{Ni}$ is concentrated in the mineral phase (Hart and Davis, 1978), what is confirmed by the high $\mathrm{Ni}$ content of olivine in ultramafic rocks. It is possible that the same Ni preference for olivine happens in carbonatite magmas but there is no data on this partition coefficient. Carbonatites characteristically contain low $\mathrm{Ni}$ (up to $\sim 50 \mathrm{ppm}$ ) contents (Woolley and Kempe, 1989) if compared to ultramafic rocks in carbonatite complexes (e.g., up to $0.46 \%$ of $\mathrm{NiO}$ for Sokli and Catalão-I). Thus the $\mathrm{Ni}$ difference in olivines from carbonatites and silicate rocks may reflect the liquid Ni content.

$\mathrm{Mn}$ is an important element in carbonatite complexes. Ilmenite in silicate and carbonatitic related-rocks present $\mathrm{MnO}$ from 1 to $5 \mathrm{wt} \%$ in average. High $\mathrm{Mn}$ contents were observed in ilmenite from syenites of the Jacupiranga Complex (up to $11 \%$ of $\mathrm{MnO}$; Gaspar, 1989). $\mathrm{Mn}$ is strongly partitionated to ilmenite in relation to magnetite regardless of whether it is primary or the result of oxidation solution (Haggerty, 1976). It is interesting to note that Mn-rich ilmenites occur in both silicate and carbonatite rocks while the Mn content discriminates olivines from carbonatite and silicate rocks (Figure 1).

The forsterite contents of olivines occurring in kimberlite groundmass range from 87 to $93 \mathrm{~mole} \%$ and $\mathrm{NiO}$ contents from 0.1 to $0.5 \mathrm{wt} \%$. They are $\mathrm{Ca}$ - and $\mathrm{Mn}$-poor $(<0.05 \mathrm{wt} \%)$ (e.g. Apter et al, 1984; Tompkins et al, 1984; Mitchell, 1986) and are chemically similar to silicate relatedolivine in carbonatite complexes, but different from carbonatite olivine.

Mantle olivines affected by carbonatitic metasomatism are described by Dalton and Wood (1993) and Hauri et al (1993). Their $m g$ number and Ca content are higher than mantle olivines not affected by carbonatitic metasomatism, however, their $\mathrm{Ni}$ and $\mathrm{Mn}$ are not similar to carbonatite olivine. Carbonatite olivines usually show high $m g$ number but the $\mathrm{Ca}$ content is not necessarily high. 


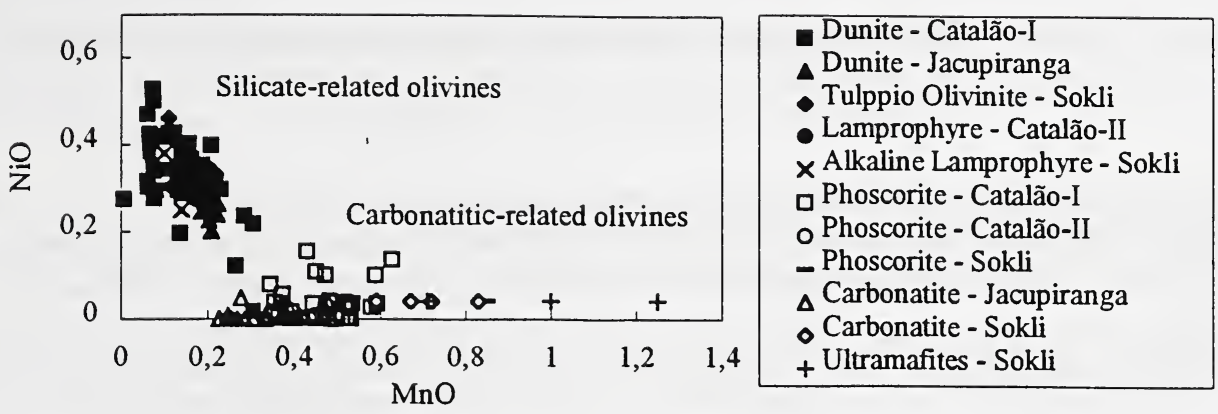

Figure 01 - $\mathrm{NiO}$ and $\mathrm{MnO}$ Contents of Olivines from Carbonatite Complexes (see text for references)

\section{References}

Amaral, G., 1978, Potassium-argon age studies on the Jacupiranga alkaline district, State of São Paulo, Brazil. Proc. I Int. Symp. On Carbonatites: 297-302.

Apter D.B., Harper, F.J., Wyatt, B.A. and Smith, B.H.S., 1984, The geology of the Mayeng Kimberlite sill complex, South Africa. In Kimberlites. I: Kimberlites and related rocks. V11A. Developments in Petrology. Ed. J. Kornprobst. Elsevier. P: 43-58.

Araújo, D.P. e Gaspar, J.C. (1994) Textural and chemical features of olivine of the Catalão-I carbonatite breccia. XXXVIII CBG.Res. Exp.:14-15 (in portuguese).

Araújo, D.P., 1996, Metasomatism in the Catalão-I Carbonatite Complex: Implication to the carbonatitic magma composition and to the upper mantle carbonatite metasomatism. MSc. Thesis, University of Brasília (in portuguese).

Bizzi, L.A., 1993, mesozoic alkaline volcanism and mantle evolution of the southwestern São Francisco Craton, Brazil. Ph.D. Thesis, University of Cape Town.

Deer, W.A., Howie, R.A. and Zussman, J., 1982, Rock-forming minerals. Vol. 11A, Orthosilicates. 2nd ed. Longman London and New York.

Ericksson, S.C. (1989) Phalaborwa: a saga of magmatism, metasomatism, and miscibility. In: Carbonatites. Genesis and Evolution. Keith Bell (ed) London. Unwin Hyman: 22 1-54.

Gaspar, J.C. (1989) Geologie et mineralogie du Complexe Carbonatique de Jacupiranga, Bresil. $\mathrm{Ph} . \mathrm{D}$. Thesis. University of Orleans. France.

Haggerty, S.E., 1976, Opaque mineral oxides in terrestrial igneous rocks. In D. Rumble, III, Ed. Oxide Mineral p.HG101-HG300. Mineralogical Society of America.

Hart, S.R. e Davis, K.E. (1978) Nickel partitioning between olivine and silicate melt. Earth Planet Sci Lett, 40: 203-19.

Lapin, A.V.(1982) Carbonatite differation processes. Int. Geol. Ver. 24(9):1079-89.Mitchell (1986)

Mitchell, R.H., 1986, Mineralogy of kimberlites. In Kimberlites. Mineralogy, geochemistry, and petrology.. ed. Penum Press. New York. p.192-7.

Sgarbi, P.B.A. e Valença, J.G., 1993, Kalsitic in Brazilian kamafugitic rocks. Min. Mag,57: 165-171.

Tompkins, L.A. and Haggerty, S.E., 1984, The Koidu kimberlite complex, Sierra Leone: Geological setting, petrology and mineral chemistry. In Kimberlites. I: Kimberlites and related rocks. V11A. Developments in Petrology. Ed. J. Kornprobst. Elsevier. P: 83-106.

Vartiainen, H. (1980) The petrography, mineralogy and petrochemistry of the Sokli carbonatite massif, northern Finland. Geol Surv Finland, Bull 313: $121 \mathrm{p}$.

Woolley, A.R. e Kempe, D.R.C. (1989) Carbonatites: nomenclature, average chemical compositions, and element distribution. in Carbonatites. Keith Bell (ed) Unwin Hyman, London : 1-14.

Yegorov, L.S. (1993) Phoscorites of the Maymecha-Kotuy ijolite-carbonatite association. Int Geol Rev, 35: 346-58.

Zaitsev, A. and Bell, K., 1995, Sr and Nd isotope data of apatite, calcite and dolomite as indicators of source, and the relationships of phoscorites and carbonatites from the Kodvor massif, Kola peninsula, Russia. Contrib. Mineral. Petrol., 121:324-35. 